\title{
Reflexões sobre a experiência religiosa a partir da hermenêutica filosófica de Gadamer
}

\author{
Newton Aquiles von Zuben* \\ Camila Medina**
}

\section{Resumo}

Este artigo apresenta um resumo das principais reflexões elaboradas em dissertação de mestrado que teve como objetivo refletir sobre o conceito de experiência religiosa, partindo do pensamento de Hans-Georg Gadamer (1900-2002) e da discussão que sua hermenêutica filosófica propõe sobre os conceitos de experiência e de verdade. Admitindo as considerações do autor sobre o caráter hermenêutico da experiência humana, pretendemos investigar se os conceitos elaborados por ele podem contribuir para o nosso entendimento sobre a experiência religiosa. Além disso, perguntamo-nos também se tais reflexões seriam capazes de oferecer concepções interessantes para a compreensão de fenômenos religiosos atuais e para os estudos no âmbito da(s) Ciência(s) da(s) Religião(ões).

Palavras-chave: Experiência religiosa. Experiência hermenêutica. Verdade. Hermenêutica filosófica. Hans-Georg Gadamer.

\section{Reflections on religious experience from Gadamer's philosophical hermeneutics}

\footnotetext{
Abstract

This article presents a summary of the main reflections elaborated in a master's dissertation that aimed to reflect on the concept of religious experience., from the thought of Hans-Georg Gadamer (1900-2002) and the discussion that his Philosophical

* Doutor em Filosofia pela Université Catholique de Louvain, Bélgica. Professor na Faculdade de Filosofia e no Programa de Pós-Graduação em Ciências da Religião da Pontifícia Universidade Católica de Campinas (PUC-Campinas).

E-mail: nzuben@puc-campinas.edu.br Currículo Lattes: K4727861H4

** Mestre em Ciências da Religião pela Pontifícia Universidade Católica de Campinas (PUC-Campinas) e em Comunicação e Cultura pela Universidade Federal do Rio de Janeiro (UFRJ). E-mail: camilabmedina@gmail.com Currículo Lattes: http://lattes.cnpq. br/8666762715407531
} 
Hermeneutics proposes about the concepts of experience and truth. Admitting the author's considerations about the hermeneutic condition of human experience, we intend to investigate whether these concepts can contribute to our understanding of religious experience. In addition, we also wonder if such discussion can offer interesting insights for understanding current religious phenomena and for Religious Studies.

Keywords: Religious experience. Hermeneutic experience. Truth. Philosophical Hermeneutics. Hans-Georg Gadamer.

\section{Reflexiones sobre la experiencia religiosa a partir de la hermenéutica filosófica de Gadamer}

\section{Resumen}

Este artículo presenta un resumen de las principales reflexiones elaboradas en una disertación de maestría que tuvo como objetivo reflexionar sobre el concepto de experiencia religiosa, a partir del pensamiento de Hans-Georg Gadamer (1900-2002) y la discusión que su hermenéutica filosófica propone sobre los conceptos de experiencia y de verdad. Admitiendo las consideraciones del autor sobre el carácter hermenéutico de la experiencia humana, tenemos la intención de investigar si los conceptos elaborados por él pueden contribuir a nuestra comprensión de la experiencia religiosa. Además, también nos preguntamos si tales reflexiones podrían ofrecer ideas interesantes para comprender los fenómenos religiosos actuales y para los estudios en la(s) Ciencia(s) de la(s) Religión(es).

Palabras clave: Experiencia religiosa. Experiencia hermenéutica. Verdad. Hermenéutica filosófica. Hans-Georg Gadamer.

\section{Introdução}

O termo "hermenêutica" vem sendo amplamente utilizado nos estudos atuais sobre a religião, principalmente designando "a disciplina, os problemas, os métodos que dizem respeito à interpretação e à crítica dos textos, especialmente dos símbolos" (HIGUET, 2013, p.457). Nesse caso, a hermenêutica é vista como uma abordagem de análise do discurso religioso, ou seja, um modo de "ler" e entender a religião a partir da interpretação da linguagem religiosa, que seria aquilo que "aparece" do "fenômeno" (este ainda algumas vezes lido como algo "puro", "real", que apenas se manifesta de uma forma - ou de formas variadas - que pode ser interpretada de modo a que se chegue à sua "verdade").

No entanto, indo a fundo no pensamento de autores como Hans-Georg Gadamer (1900-2002), que pensou a hermenêutica como teoria filosófica (ou ainda, como base da própria filosofia e da compreensão humana), percebemos que, ao tratarmos da relação entre hermenêutica e religião, mais do que a 
utilizarmos como ferramenta de interpretação do fenômeno religioso (ou de sua linguagem), é importante também observar como ela é uma dimensão intrínseca ao próprio fenômeno e condição mesma de sua existência enquanto tal. Essa reflexão é importante não para negar a hermenêutica enquanto método ou disciplina, mas para que, ao colocarmos a religião como objeto de observação, haja clareza de que é apenas isso que estamos fazendo: delimitando um objeto que tem, ele mesmo, seus pressupostos e suas interpretações (não sendo aí, portanto, um mero e puro objeto). Tal reflexão parece ser importante para que não caiamos em relativismos ou dogmatismos, ainda frequentes em nosso campo de estudos.

Assim, propomos pensar a religião e, especialmente, a experiência religiosa, como experiência hermenêutica, tal como essa experiência foi definida por Gadamer. Antes, faz-se necessário apresentar muito brevemente o que o autor entende por experiência hermenêutica e sua relação com o conceito de verdade, bem como problematizar alguns conceitos, tais como "religião" e "experiência religiosa". Por fim, propomos pensar sobre essa experiência do ponto de vista gadameriano, indicando que sua dimensão "hermenêutica autêntica" (que estamos chamando aqui de "experiência da verdade") não é exclusiva do âmbito religioso, e quais seriam algumas implicações possíveis a partir de tais considerações.

\section{A verdade enquanto acontecimento e a experiência hermenêutica}

A tese heideggeriana de uma estrutura prévia da compreensão modificou o papel da hermenêutica, que "deixou de ser empregada como um método próprio das ciências do espírito, para contribuir para a análise do modo de ser do ser humano, inclusive de ser capaz de fazer ciência" (PEREIRA, 2015, p. 165). Seguindo a esteira de Martin Heidegger, para Gadamer, "compreender" ou "interpretar" não significa mais "um comportamento do pensamento humano dentre outros que se pode disciplinar metodologicamente, conformando assim a um procedimento científico, mas perfaz a mobilidade de fundo da existência humana" (GADAMER, 2011, p.125).

A partir desse ponto de vista, que entende o homem como um ente cujo existir é essencialmente compreensivo, Gadamer propõe um entendimento sobre a verdade como algo que se dá enquanto acontecimento em um horizonte de compreensão. A linguagem aqui assume papel primordial, tendo em vista que, mais do que mera ferramenta da comunicação humana, 
que apenas reflete sobre ou transmite algo já conhecido e consciente, para Gadamer, ela é o próprio meio onde ocorre a experiência hermenêutica, não sendo possível compreensão fora dela. Assim, a verdade só poderia ser encontrada no próprio ato de compreender, no diálogo entre aquele que conhece e aquele que se dá a conhecer.

A hermenêutica filosófica proposta pelo autor foi elaborada exatamente como forma de resgatar um outro entendimento sobre a verdade, mais apropriado para as ciências humanas, a filosofia, e outros modos de compreensão da realidade pelo homem da qual, segundo Gadamer, a ciência (ou a ideia de verdade moderna, proposta pela ciência) não dá conta. Ao nosso ver, ao pensarmos sobre a experiência religiosa, é interessante seguir também esse caminho de pensamento, principalmente se levarmos em conta que a questão da verdade é, possivelmente, uma das questões mais fundamentais colocadas tanto pelas próprias religiões quanto por aqueles que as estudam (principalmente nos campos da teologia ou da filosofia da religião).

Em poucas palavras, o autor entende que, na modernidade, verdadeiro é aquilo que satisfaz o ideal de certeza. Aqui o lugar da verdade é o juízo, e ela somente pode ser determinada pela adequação do discurso à coisa. Compreender verdadeiramente algo, ou compreender a verdade de algo, seria então verificar (muitas vezes por meio de um método) se nossa elaboração racional sobre esse algo é adequada ou corresponde à sua realidade. No entanto, Gadamer sugere que nem sempre é assim que ocorre. Há questões que essa ideia de verdade não responde (ou nem mesmo realiza). E, para o autor, ainda que não haja respostas fechadas, tais questões continuam devendo ser colocadas.

Sendo assim, ele resgata a concepção heideggeriana de verdade, como desocultação, desvelamento, ou seja, algo que simplesmente se dá ao homem pela própria realidade das coisas, na medida em que eles (o homem e as coisas) se relacionam em um mundo e no tempo. Esse "ser" das coisas que se revela, no entanto, por conta exatamente das condições da realidade do homem (o tempo e a linguagem), ao mesmo tempo deixa muito de si encoberto ou velado, não podendo o acesso à verdade nunca ser pleno ou completo. A verdade aqui, então, não é uma essência do objeto (no sentido de uma característica sua) que é descoberta ou obtida pelo sujeito, mas se coloca como um acontecer que se dá na relação entre sujeito e objeto. A verdade aqui seria aquilo que se dá, portanto, na própria experiência (e não como resultado dela), que transforma tanto o "objeto" (eu o defino, e de certa maneira, o 
reduzo, ao tentar "descobri-lo") como o "sujeito" (ao compreender o objeto, dialogando com ele, posso compreender a mim mesmo).

Para propor esse novo entendimento sobre o conceito de verdade, Gadamer promove uma discussão sobre a experiência da arte, trazendo a noção de jogo para exemplificá-la. O termo "experiência", no entanto, para ele, não se reduz à experimentação metódica e objetiva, sendo a interpretação, a compreensão, e portanto o conhecimento, uma elaboração a posteriori; e nem apenas uma experiência sensorial, calcada nas sensações, que só depois a racionalidade e a subjetividade dá um sentido (uma interpretação). A experiência, para Gadamer, é já experiência de sentido, é já interpretação e compreensão do outro, que não é colocado mais somente como "objeto", mas como "interlocutor", na medida em que a experiência, sendo sempre relacional e mediada pela linguagem, é também dialética (e histórica).

Isso não quer dizer que a limitação da finitude e da linguagem humana tenham uma conotação somente negativa (no sentido que já vimos, de que a verdade nunca poderá ser completamente ou absolutamente conhecida). O fato de que ela nunca se mostra totalmente, faz com que a experiência hermenêutica seja essencialmente "abertura", ou seja, possibilita que o homem esteja sempre aberto e diante da possibilidade de compreender mais e melhor. Como afirma Andrade Júnior, "o homem, pela experiência, pode livrar-se de um destino de impossibilidade de avanço quanto à verdade enquanto puder experimentar, nunca desistir de alargar seu horizonte de compreensão" (ANDRADE JUNIOR, 2010, p.19).

Uma experiência hermenêutica autêntica, portanto, para Gadamer, seria aquela em que o homem, consciente de sua própria historicidade, consegue dialogar com a tradição, colocando em jogo seus próprios preconceitos e deixando o outro, em seu horizonte, falar. É nessa relação dialógica, nesse jogo, que a verdade acontece. Um bom exemplo para entendermos como isso se dá é a da execução de uma música por uma orquestra. A música, em sua verdade, só acontece no momento da execução e na medida em que toca o ouvinte. Ela é a partitura, mas não só; ela é a intenção do compositor, mas não só; ela é a execução de cada instrumento, mas não só; ela é a apreensão sensorial e subjetiva de quem escuta, mas não só. Sua verdade se dá nesse momento em que acontece, de todas essas formas, na medida em que toca e transforma todos os envolvidos nessa relação, mas ainda é bem mais que isso. É uma verdade maior, superior, não como uma realidade enquanto uma ideia fixa que se concretiza em qualquer execução que se realize, mas como 
possibilidade, que vai acontecendo e sendo conhecida de maneiras diferentes a cada execução.

Ora, partindo dessa premissa que o homem é um ser hermenêutico e que compreender é, fundamentalmente, interpretar (o que implica dizer que, em última instância, o conhecimento da verdade passa também pela interpretação), como fica a questão da verdade no âmbito religioso? Se o discurso religioso comumente se define, exatamente, por ser expressão da verdade ou fruto de seu conhecimento, como algo único e imutável, como assumir, nessa esfera, a perspectiva da hermenêutica filosófica? A ideia de uma ontologia da linguagem e de que a verdade não é mera adequação a uma realidade, mas se dá enquanto acontecimento, nos dá as pistas para entendermos em que medida essa relação é possível, ao considerarmos a religião e a própria experiência religiosa como experiência hermenêutica. Antes de propor essa análise, no entanto, faz-se necessário discorrermos sobre o que estamos entendendo aqui por "religião" e por "experiência religiosa".

\section{Sobre o conceito de religião}

Quando falamos de religião, principalmente em nosso cotidiano, parecemos saber bem do que se trata. Às vezes usando como sinônimo de instituição religiosa, às vezes como religiosidade em geral, não temos medo de denominá-la e, caso encontremos objeções, o termo pode ser facilmente explicado, nem que seja incluindo o adendo de que tal explicação se trata, simplesmente, da própria opinião. Isso porque, a depender do contexto e da formação religiosa do indivíduo, uma prática pode ou não ser considerada como tal (geralmente em comparação com a sua própria). Também as próprias organizações que, de algum modo, parecem lidar com o que poderia ser considerado um "fenômeno religioso", ou que possuem suas doutrinas e rituais específicos, por vezes podem se apresentar de outra forma, como organizações ou sistemas de crenças de cunho filosófico, por exemplo. Esse cenário já demonstra que não há uma definição clara ou universalmente aceita sobre o conceito.

No âmbito acadêmico, o problema se torna ainda mais evidente, principalmente no campo em que nos encontramos, o da(s) Ciência(s) da(s) Religião(ões), uma vez que suas referências são interdisciplinares e plurais. Por isso, torna-se sempre necessário, ao falarmos sobre o assunto, se não formos problematizá-lo, pelo menos indicarmos o ponto de onde estamos partindo ou as definições que estamos utilizando. 
Fato é que, ao refletirmos sobre esse conceito, frequentemente nos direcionamos à sua etimologia. Uns dos autores mais citados em relação ao assunto são Filoramo e Prandi, que em seu livro As ciências das religiões apresentam-nos as origens etimológicas do termo, considerando o itinerário histórico de sua elaboração e aplicação. Sendo o termo de origem latina, os autores atribuem a Cícero (aproximadamente 45 a.C.) a melhor definição para o que era a religião romana. Segundo eles, afirmando que o termo religio derivava de relegere, Cícero sugeriu que a religião se baseava "na escrupulosa observância do rito e, por isso, na precisão repetitiva dos atos devocionais dirigidos à divindade" (FILORAMO e PRANDI, 1999, p.256). No entanto, com o advento do cristianismo, seria necessário adequar a origem do termo ao que significava essa nova religião. Foi então Lactâncio (séc. III-IV d.C.) que propôs que a etimologia de religio não seria relegere, mas sim, religare, assim significando que a religião seria, portanto, um laço de piedade com o qual o homem se uniria e (re)ligaria a Deus.

A partir daí, a ideia de que religio provém de religare foi se impondo e sendo transmitida para a cultura cristã posterior, que permaneceu associando o termo à religião "verdadeira" (ou seja, enquanto laço que re-liga o homem ao "verdadeiro" Deus). A superstição e o charlatanismo passaram a ser associados a qualquer prática pagã e não mais somente àqueles que, ao contrário dos religiosos da Roma antiga, não observavam os ritos com devoção e cuidado, tratando-os superficialmente. Cristiane Azevedo cita o linguista Émile Benveniste indicando que, segundo este autor, portanto, "o conceito de religio se modifica e se remodela de acordo com a ideia que o homem tem da sua relação com Deus", sendo a ideia cristã "completamente diferente da velha religio romana" e aquela que "prepara para a acepção moderna do termo" (AZEVEDO, 2010, p.95).

De fato, parece ser essa a ideia que serviu de base para a concepção moderna de religião, inclusive dentro do debate levantado a partir do Iluminismo, cuja crítica voltada à religião parecia identificá-la principalmente com o cristianismo. É então nesse momento que surge novamente o problema da definição, uma vez que o contato dos europeus com outras culturas aumenta (e também o interesse e o estudo científico sobre elas), fazendo-os reconhecer manifestações semelhantes às consideradas religiosas por eles (embora, nessas outras culturas, lhes fosse estranho esse termo).

Filoramo e Prandi citam os discursos de Schleiermacher sobre a religião, proferidos em 1799, recomendando aos intelectuais da época que a 
criticavam que não abordassem apenas uma religião mas examinassem todas as que "foram historicamente se realizando nas diversas civilizações do globo", considerando, assim, a complexidade e a multiplicidade dos conteúdos da palavra "religião" (FILORAMO e PRANDI, 1999, p.253). Segundo os autores, nesses discursos o filósofo alemão queria opor-se a uma definição funcional do termo, colocando "o foco em algo substantivo (isto é, tendente a fixar a sua essência)" e aí propunha a definição de religião como "sentimento do Infinito” (FILORAMO e PRANDI, 1999, p.253, grifo dos autores).

No entanto, para eles, mesmo admitindo a complexidade e amplitude do termo nesse caso, a questão semântica permaneceria aberta, uma vez que, independente de considerar a religião de um ponto de vista mais funcional ou por um viés mais essencialista, a ideia moderna sobre o termo parece, de fato, seguir o caminho apontado pela origem religare. Porém, sugerir, como Benveniste, que essa etimologia seja desconsiderada em prol de relegere, que seria a "verdadeira origem etimológica" do termo (cf. AZEVEDO, 2010, p.95), não parece uma boa solução. Isso porque corresponder a palavra "religião" a somente aquilo que significava como religio romana é novamente reduzir uma gama ampla e complexa de fenômenos que podem ser considerados religiosos, além de desconsiderar toda a tradição acerca do termo que, de maneira ou de outra, contribuiu para a noção que temos hoje sobre ele e dos usos que fazemos.

Percebemos aí, portanto, que mesmo quando se busca a etimologia de uma palavra, há a necessidade de se levar em conta o processo histórico de sua elaboração e seus usos atuais, caso contrário, corremos o risco de supor que há uma verdade a priori sobre o conceito ou que conhecer a sua origem seria a melhor (ou talvez a única) forma de entender não só o conceito mas também de identificar e compreender o fenômeno ao qual ele se refere. É o que a problematização apresentada por Frederico Pieper propõe, ao olhar para esse termo através da história, observando seus usos e aplicações. Obviamente esse esforço acaba por incorporar também o trabalho etimológico realizado ao longo do tempo e considera, em alguma medida, suas acepções, uma vez que, ao refletir sobre determinado conceito ao longo da história, colocamonos em diálogo com a tradição e devemos partir de algum horizonte, como veremos a seguir.

Segundo Pieper, a noção de religião tal como utilizamos hoje, tanto no senso comum quanto academicamente, começou a ser amplamente utilizada na modernidade, com a autonomização das esferas sociais provocada por 
ela (PIEPER, 2019, p.12). Além disso, o termo somente faz parte do léxico ocidental "não encontrando correspondentes em muitos sistemas linguísticos", significando, assim "que muitas pessoas são ditas 'religiosas' sem conhecer nenhum termo em sua própria língua que corresponda a essa 'coisa' ou região da cultura que assim denominamos" (PIEPER, 2019, p.8).

Ou seja, o pensamento moderno iluminista, ao buscar compreender o mundo, identificando-o como objeto de estudo, classificou práticas sociais e culturais (também aí já considerando conceitos específicos de "sociedade" e "cultura") e destacou uma delas como isso a que chamamos "religião", tendo como base principal para essa compreensão o cristianismo e seu conceito de religare. Ao longo do tempo, por analogia ou intenção, o termo passou a ser utilizado também na observação de fenômenos estranhos àquele, o que gerou já naquela época e tem gerado até hoje discussões sobre a possibilidade ou não de nomear certos fenômenos como religiosos e tomá-los como objeto.

Diante dessa constatação de que o termo "religião" (assim como qualquer outro) deve ser sempre analisado a partir de sua situação histórica e que não há origem ou etimologia que possa significar o que o conceito em si quer dizer de fato, percebemos a dificuldade de encontrarmos uma descrição universal, que sirva a todos os fenômenos ditos religiosos. Isso não quer dizer que não devamos mais usar o termo (até porque, ao tentar refletir sobre o assunto, teríamos que substituí-lo por outro e cairíamos no mesmo dilema). Como afirma Derrida, "nem sempre houve, continua não havendo e nunca haverá por toda a parte algo, uma coisa una e identificável, idêntica a si mesma que leve religiosos ou irreligiosos a ficar de acordo para lhe atribuir o nome de 'religião'. E, no entanto, diz-se, é necessário responder” (DERRIDA, 2000, p.52). É o que também afirma Pieper:

Nessa medida, parece ser muito apressado dispensar um conceito porque ele simplesmente não corresponde a uma realidade objetiva. É claro que não há algo como a "religião" no mundo objetivo. Mas, o que esse conceito nos proporciona é, justamente, o acesso a elementos que denominamos religiosos. Como interpelar uma religião específica sem esse conceito mais amplo de fundo? Esses conceitos não deveriam ser avaliados, unicamente, pela sua capacidade de descrição ou de se referir a fatos. Antes, eles deveriam ser perguntados sobre em que medida e onde abrem ou limitam o pensar. $\mathrm{O}$ mérito da desconstrução do conceito de religião está, então, em indicar que a noção de neutralidade no estudo da religião é falaciosa. (2019, p.14). 
Ou seja, utilizar um conceito ao analisar um fenômeno é uma tentativa não só de descrever e entender algo já dado, mas identificá-lo e classificá-lo a partir de uma compreensão prévia. Por isso, é necessário admitir que ele não serve apenas para nomear e definir um fenômeno empírico já observado, mas também como condição mesma da observação. Considerando, no entanto, que é impossível abandonar o conceito de vez, nosso intuito é, seguindo o proposto por Pieper, defender a possibilidade de utilizar o conceito não só como referência mas também como horizonte.

Dessa maneira, quando falamos em religião primitiva, por exemplo, ou sobre uma religião oriental, ou ainda sobre novas religiosidades, quer dizer meramente que estamos destacando alguns aspectos de certos fenômenos culturais, que, ao nosso olhar, se parecem com os que consideramos religiosos (a partir de algumas definições já elaboradas, conscientes ou não). Isso não quer dizer que uma essência religiosa (no sentido de ideia a priori, atemporal ou absoluta) exista, mas que há, nesses fenômenos, elementos considerados comuns e que foram sendo sistematizados como religiosos ao longo da história.

A partir daí, entendendo que precisamos identificar o horizonte de onde partimos, ou seja, indicar que noção de religião estamos utilizando, cremos ser interessante apresentar as considerações de Jean Grondin sobre o conceito. O autor, que é, inclusive, biógrafo e comentador de Gadamer, ao escrever sobre a filosofia da religião, parte de alguns pressupostos, considerando como marcas que carregamos em nossas reflexões sobre o fenômeno tanto o cristianismo quanto a filosofia grega, além de também discorrer sobre as questões etimológicas já apresentadas anteriormente.

Ciente de que o fenômeno religioso admite formas variadas e na tentativa de englobar a maior parte dessas formas em uma definição útil, o autor se pergunta pela "essência" da religião, não com o objetivo de descobrir uma ideia a priori mas de procurar responder à questão, segundo ele, "mais elementar": "de que se fala quando se trata de religião? O que se mantém no fenômeno religioso através de todas as suas metamorfoses?" (GRONDIN, 2012, p.28). Assim, sua intenção é a de, a partir de sua reflexão sobre o que é religião, identificar as características comuns dos fenômenos identificados como tal.

Grondin define então religião como um "culto crente", "que se traduz por símbolos que reconhecem um sentido para nosso universo" (GRONDIN, 2012, p.39), sendo "culto crente", em seu ponto de vista, uma elaboração acerca de algo bem amplo, que ora pode estar mais próximo da dimensão do culto (ao modo das religiões mais arcaicas, mais rituais ou 
baseada em mitologias), ora mais próximo da dimensão da crença (como as religiões modernas, conscientes de si mesmas como religiões e que se compreendem como crenças). Ou seja, todas as religiões comportariam essas duas dimensões, porém, a depender da religião, haveria mais elementos de um ou de outro nela. Segundo o autor, em todas as tradições religiosas, haveria também sempre o sentimento de que há algo para além ou anterior ao ser humano, que dá sentido à sua existência e fundamenta suas verdades estabelecidas (seus credos, doutrinas, práticas ou filosofias). Religião seria, portanto, a expressão da "dimensão simbólica do real e da vida", na qual "o real é mais do que ele dá a perceber à primeira vista", pois "tem um sentido" (GRONDIN, 2012, p.38).

Considerando tudo o que já comentamos acerca do uso dos conceitos, poderíamos dizer que não é bem que todas as religiões (enquanto realidades dadas) comportam essas duas dimensões (do culto e da crença), mas que tudo aquilo que identificamos como comportando essas duas dimensões e tendo as características elencadas pelo autor (a busca de sentido para a existência por meio de linguagem simbólica, por exemplo) pode ser enquadrado como religião. Nesse sentido, admitindo as limitações dessa classificação, optamos por ela não só porque procura ser abrangente e parece integrar bem muitos elementos daquilo que chamamos hoje de fenômeno religioso, mas também porque vai nos permitir desdobrar a reflexão sobre a experiência religiosa, desconstruindo sua própria definição.

\section{Sobre a experiência religiosa}

Para algumas vertentes de ciências como sociologia, antropologia, história e psicologia, religião é apenas uma construção humana, sendo uma das formas como os homens encontraram de se relacionarem com o mundo, compreendê-lo ou explicá-lo. Nessa perspectiva, a expressão "experiência religiosa" quase não é utilizada, preferindo-se termos como "vivência", "prática" ou até mesmo "crença" religiosa, no intuito de evidenciar ora o caráter social e cultural da religião, ora o subjetivo. Assim, uma experiência religiosa, aqui, poderia ser considerada numa perspectiva meramente empírica, uma experiência que o sujeito realiza com o mundo e com os outros, a partir de um sistema religioso ou utilizando certa linguagem identificada como religiosa. Em um âmbito mais subjetivo, por exemplo, uma experiência religiosa poderia ser considerada simplesmente um transe psíquico ou, até mesmo, uma patologia. 
Considerando essa ideia, tanto o fenômeno religioso enquanto realidade, quanto a religião enquanto esfera social autônoma são negados. A religião aqui é, segundo Pieper, reduzida a outra esfera social ou empregada como meio para se compreender a cultura e a sociedade. No primeiro caso, "cabe destacar a abordagem crítica da religião (presente nos mestres da suspeita como Feuerbach, Marx, Nietzsche, Freud)" que "não somente identifica a origem da religião em outra esfera social, como busca apontar caminhos para que, superadas as situações que sustentam a religião, ela seja superada" (PIEPER, 2015, p.15-16).

Já o segundo caso, ou seja, a tendência que vê a religião apenas como meio para se compreender a cultura ou a sociedade, "podemos chamar, na falta de um termo melhor, de funcionalista. Ao invés de perguntar pela origem da religião, a questão central é por sua função social. [...] Em suma, nessa perspectiva, a religião é espécie de meio para se chegar a um fim" (PIEPER, 2015, p.16-17). Aqui, podemos dizer que a existência de uma realidade ou uma essência religiosa também não é considerada. Um dos fundadores dessa tendência foi Émile Durkheim, autor do clássico As formas elementares da vida religiosa, publicado em 1912, para quem "a dinâmica religiosa só pode ser identificada sociologicamente, na objetividade do fato religioso, como fato social" (FILORAMO e PRANDI, 1999, p.99). Assim, a religião é caracterizada como uma força coletiva, de caráter funcional, organizada por meio de um sistema (ritos). Outro autor importante para a história dos estudos sociológicos sobre a religião, Max Weber, também considerava a religião como "um fato cultural de natureza não transcendente" e, apesar de não definí-la, procurou investigar as interações entre mecanismos sociais e universos religiosos (FILORAMO e PRANDI, 1999, p.105). Segundo Filoramo e Prandi, também se enquadram nessa tendência as escolas de antropologia cultural, atenta aos comportamentos, técnicas, linguagens e símbolos religiosos, e de antropologia social, que segue a articulação das instituições (inclusive sistemas de parentesco).

De acordo com Pieper, além dessas duas possibilidades de articulação do fenômeno religioso (a tendência crítica, que reduz a religião a uma esfera psicológica ou social, e a funcionalista, que procura compreender a cultura como um todo, por meio da religião) há uma terceira, que entende a religião como esfera social autônoma e busca explicá-la a partir dela mesma. Nessa perspectiva, de cunho fenomenológico, a religião teria origem em algo religioso, "de modo que cabe investigar justamente o que caracteriza esse 
religioso (seja ele denominado de força, hierofania, mysterium tremendum et fascinans, etc)" (PIEPER, 2015, p.18).

Tais denominações pertencem a autores como Gerard van der Leeuw, Mircea Eliade e Rudolf Otto. Para o primeiro, de acordo com Angela Ales Bello, o poder (como algo diferente do próprio sujeito que realiza a experiência religiosa e que o surpreende, ou seja, algo emanado pelo objeto da experiência) seria o elemento essencial comum a todas as religiões. Segundo Van der Leeuw, a estrutura da religião remeteria a uma situação existencial que caracteriza o ser humano, que, frente a esse poder, "procura elevar a sua vida, aumentá-la, conquistar-lhe um sentido mais amplo e mais profundo" (ALES BELLO, 1998, p. 108). Para ele, portanto, o sentido último da existência, seu extremo significado, seria o religioso.

Mircea Eliade é também um dos nomes mais conhecidos nos estudos das religiões, tendo realizado pesquisas comparadas e elaborado conceitos como sagrado, profano e hierofania (que seria a manifestação do sagrado). De acordo com Filoramo e Prandi, a intenção do autor era, com sua morfologia e método classificatório, entender um fenômeno religioso em seu próprio modo de ser, naquilo que ele tem de irredutível e original. No entanto, para ele, dado que um fenômeno religioso nunca é separado da história, o caminho de um estudo possível, frente à multiplicidade dos fenômenos desse tipo, deveria ser analisando os símbolos religiosos, mediadores da hierofania (FILORAMO e PRANDI, 1999, p.55-56). Ainda para Eliade, o sagrado, além de identificado com algo real, seria também um elemento da estrutura da consciência.

Mas é com Rudolf Otto que o conceito de sagrado ganha força. $\mathrm{O}$ autor parte de relatos de experiências religiosas (principalmente a partir de religiões monoteístas, mas não somente) para chegar à noção de numinoso, que seria a indicação do sagrado como uma profunda experiência emocional, de aspecto tremendum (arrepiante), majestas (avassalador), enérgico, fascinante e assombroso, que não pode ser explicitado por conceitos, sendo considerado, por isso, irracional (OTTO, 2007). Nessa perspectiva, o "sagrado" se trata de uma realidade transcendente ao homem que se manifesta a ele, transformando-o e conferindo-lhe sentido. Como afirma José Severino Croatto:

Confirmamos, então, o que já havíamos indicado, a saber: que é a experiência do transcendente, do Mistério, a chave para compreender a linguagem do sagrado em suas infinitas expressões. Dito isso, como designar a meta transcendente da experiência religiosa? Uns a chamam de "Deus", como fazemos em nossa tradição judaico-cristã e como acontece em muitos outros casos. [...] Vários 
termos foram assinalados, marcando a potência do transcendente (orenda, mana, numen etc.). Essa potência não está necessariamente personificada; [...] às vezes, é ambivalente, como se revela pelos ritos criados para atraíla (como divina e benéfica) ou rejeitá-la (como demoníaca e destrutiva). Antes de chegar ao Deus concebido como pessoa, alguns autores preferem referir-se simplesmente ao "totalmente Outro" (como fez Rudolf Otto), ou simplesmente ao Mistério como o transcendente vivido na experiência religiosa. As duas designações destacam o negativo: algo absolutamente diferente de qualquer realidade humana e que não se pode conhecer. Isso indica uma qualidade dessa Realidade transcendente: a ela é que pertence a iniciativa de manifestar-se. (2001, p.61-62, grifos do autor).

Assim, segundo Carlo Greco, "o vivenciado religioso apresenta-se no horizonte fenomenológico como determinado pelo movimento revelador de um objeto absoluto, que permanece sempre além de suas próprias manifestações", sendo sua presença apreendida na mediação dos símbolos (GRECO, 2009, p.120-121). Ou seja, para a fenomenologia, se é possível dizer algo como experiência religiosa (que somente poderia ocorrer entre um sujeito e um objeto), quer dizer que há, mesmo, um fenômeno religioso, que se coloca como objeto da experiência. Dessa forma, nesse pensamento, parece óbvio assumir que há tanto um a priori religioso no homem (o sujeito da experiência) como uma realidade religiosa "totalmente outra" (o fenômeno, objeto da experiência). Nota-se, aí, que, embora também cultos, orações e ritos possam ser considerados "experiências religiosas" (no sentido de que, como afirma Ales Bello (1998, p.121), as religiões "constituem a manifestação exterior da consciência religiosa que se pode captar através dos atos e lugares de culto, bem como através das doutrinas que são vez por vez elaboradas e aquelas que podem ser deduzidas de forma indireta das narrativas e das crenças"), o conceito foi se desenvolvendo de modo a definir aquela experiência mais individual de encontro com o sagrado.

Assim, como podemos perceber, a fenomenologia da religião, em sua vertente mais clássica, ao procurar ir à religião ela mesma, buscando sua essência, acabou, na maioria das vezes, entendendo a experiência religiosa principalmente nesses termos (sujeito x objeto), identificando este objeto como uma realidade transcendente que, embora misteriosa, não totalmente definível e conhecível, existe, de fato, enquanto realidade religiosa e que a consciência experimenta.

Martin Heidegger foi o responsável por uma virada importante nessa tendência, lançando as bases para uma fenomenologia hermenêutica. Sua 
filosofia, ao tomar como ponto de partida a ideia de "experiência fática da vida", propõe que "a experiência da vida é mais que a mera experiência de tomada de conhecimento", mas significa "a plena colocação ativa e passiva do homem no mundo". Assim, o experimentado, o vivido, é definido enquanto "mundo", não como "objeto" (HEIDEGGER, 2010, p.15-16). Isso implica que a experiência não é mais compreendida nos termos sujeito x objeto, como na fenomenologia clássica. Para Cezar Seibt, a fenomenologia de Heidegger, o seu retorno às coisas mesmas, não trata "do retorno a algum ente específico ou dimensão, faceta ou ângulo de algum ente para completá-lo ou somar informações" e nem das "vivências da própria consciência pura (consciência que pode ser separada do mundo como 'eu puro')" (SEIBT, 2018, p.128-129). Como afirma o próprio Heidegger:

Eu experimento a mim mesmo na experiência fática da vida ou como conjunto de vivência, ou como conglomerado de atos, não como qualquer coisa de euobjeto em sentido determinado, mas naquilo que faço, no que me acompanha e sucede, no que me faz padecer, em meus estados de depressão e elevação, entre outros. Eu mesmo, em momento algum, experimento meu eu em separado, mas já sou e estou sempre preso ao mundo circundante. (2010, p.17-18, grifos do autor).

Heidegger critica, então, a ideia da filosofia da religião da época (segundo ele, conforme sistematizada por Ernst Troeltsch) que identifica a essência da religião a partir de quatro aspectos: uma essência psicológica, uma essência gnosiológica (o a priori da razão religiosa), uma essência histórica (apenas no sentido de uma tipologia geral, na medida em que a essência psicológica e a gnosiológica se realizam na história), e uma essência metafísica (o religioso como princípio de todo o a priori). Para ele, essa caracterização não brota da religião enquanto tal, mas é "encaixada à força nas disciplinas filosóficas", que consideram e classificam "o religioso como objeto" (HEIDEGGER, 2010, p.29, grifo do autor).

Sobre o conceito de “mundo", Heidegger esclarece: “'Mundo' [Welt] é algo no qual se pode viver (num objeto não é possível viver). O mundo pode ser formalmente articulado como mundo circundante [Umwelt] (Milieu), como aquilo que nos vem ao encontro, ao qual pertencem não apenas coisas materiais, mas também objetualidades, ideias, ciências, artes etc. Nesse mundo circundante também está o mundo compartilhado [Mitwelt], isto é, outros homens numa característica fática bem determinada: como estudante, docente, parente, superior etc. - não enquanto exemplar do gênero bomo sapiens das ciências naturais e assim por diante. Finalmente, aí está também o eu mesmo [Ich-Selbst], o mundo-próprio [Selbswelt], na experiência fática da vida." (HEIDEGGER, 2010, p.16, grifos do autor). 
Assim, Heidegger inaugura uma nova fenomenologia, que não busca se ocupar dos objetos específicos e suas manifestações, mas "se aproximar daquilo que é condição de possibilidade para que os objetos enquanto tais possam ser isso que são, e dos quais se possa predicar verdade ou não", ou seja, buscar a "verdade do ser" e não a "verdade do ente", a verdade num sentido originário, identificada como condição para que os entes se mostrem, como abertura, como "mundanidade do mundo" (SEIBT, 2018, p.134). Essa fenomenologia que busca o ser (que, para ele, teria sido esquecido pela filosofia e ciência modernas), deve ser hermenêutica, na medida em que se tem consciência de que o acesso à coisa nunca é pleno e imediato, e está sempre submetido à faticidade da vida. Nesse sentido, o próprio ser jamais se manifesta completamente, deixando sempre algo encoberto (ou possibilidades não realizadas), e o homem é entendido não mais como um sujeito em oposição a um objeto, mas como ser-aí (Dasein), pois somente é na medida em que experimenta o mundo, se encontra nele e em relação com ele. Tal identificação do homem como ser-aí demonstra também o caráter existencial da hermenêutica, na medida em que, não havendo a possibilidade do acesso pleno à coisa e sendo o ser-aí um ser de linguagem, seu modo de ser é sempre compreensivo (e interpretativo).

Essa virada heideggeriana foi de importante contribuição para a hermenêutica filosófica de Gadamer, que, por sua vez, influenciou o campo da fenomenologia e da hermenêutica da religião contemporâneas, bem como da teologia. No entanto, percebe-se que essa influência nem sempre incorporou a radicalidade dos pensamentos de Heidegger e Gadamer, tendo ficado, principalmente, no âmbito da interpretação dos textos, narrativas e símbolos religiosos.

É o que fica evidente na visão de Greco, quando afirma que «a passagem da inteligência fenomenológica dos dados para a hermenêutica é solicitada pela própria natureza da linguagem mítico-simbólica da experiência religiosa» e que «a fenomenologia oferece à hermenêutica os dois pressupostos: o sujeito e o dado, purificados da operação das épocas e, portanto, reconduzidos a sua autenticidade originária. Contudo, sujeito e dados são oferecidos na relação de uma intencionalidade recíproca» (GRECO, 2009, p.125-126). Segundo o autor, assumir a ideia hermenêutica da pré-compreensão, considerando agora o sujeito (antes posto em parênteses no momento fenomenológico) interpretante com seus preconceitos e sua tradição, associado ao caráter simbólico da linguagem religiosa (que esconde sentidos indiretos e figurados), abre caminho para os 
conflitos de interpretações. Diante desses conflitos, surgem as hermenêuticas desmistificadoras (associadas por Greco à tendência crítica da religião dos "mestres da suspeita", vista anteriormente) e as hermenêuticas instauradoras, mais abertas à escuta e à atenção ao dado "para qual o método fenomenológico educa" (GRECO, 2009, p.127-129).

Para ele, essas hermenêuticas instauradoras se dividem entre aquelas que se colocam em chave de imanência e aquelas que se colocam em chave de transcendência. As primeiras seriam aquelas aproximações funcionalistas, podendo ser de caráter antropológico-cultural, sociológico e psicológico. Segundo o autor, apesar da contribuição positiva dessas ciências para a "averiguação do significado do fenômeno religioso e para o reconhecimento de sua utilidade para a vida individual e social do homem" e do "respeito" que demonstram ao fenômeno religioso em si, o fato de, em nome de um pressuposto metodológico científico, não considerarem a "verdade existencial" (a existência do sagrado) que, para o sujeito religioso, é indivisível da ontológica, prejudica que se interprete verdadeiramente a consciência religiosa (GRECO, 2009, p.173-174).

Assim, apresenta como solução uma hermenêutica instauradora em chave de transcendência que, "livre de apriorismos ideológicos e metodológicos, e mais aderente ao movimento intencional da consciência religiosa, se proponha a interpretar a linguagem da experiência religiosa como expressão de uma relação real do homem com a transcendência". Tal hermenêutica seria justificada pelo que a análise fenomenológica já concluiu (e que é, a seu ver, o método mais pertinente para a filosofia da religião). Ou seja, trata-se de uma hermenêutica que, para restaurar o sentido da experiência religiosa, deve estar "apta a reconhecer o alcance revelador e ontológico dos símbolos do Sagrado e de experimentá-lo conceitualmente" (GRECO, 2009, p.174-176). Em outras palavras, para ele, uma análise da experiência religiosa que escute e respeite aquele que realiza a experiência somente pode ser realizada a partir de uma hermenêutica que esteja disposta a considerar o sagrado como pressuposto, na medida em que ele é entendido como real pela consciência religiosa. Segundo o autor, as maiores figuras dessa vertente são a hermenêutica escatológica dos símbolos do Sagrado, de Paul Ricoeur, a hermenêutica ontológica da linguagem, de Luigi Pareyson, a hermenêutica da religião como relação ética, de Emmanuel Lévinas, e a hermenêutica fenomenológica da religião entre obrigação ética e desejo de infinito, de Armido Rizzi. 
Assim, percebemos que, apesar de se apropriarem de conceitos da hermenêutica filosófica e considerarem alguns dos seus pressupostos ao olharem para o fenômeno religioso, muitos estudos filosóficos sobre a religião permanecem ainda no terreno da fenomenologia clássica (ao menos no que diz respeito à noção de experiência como a relação com uma realidade ou essência religiosa, nos termos da dicotomia sujeito x objeto). Ao afirmar que as hermenêuticas desmistificadoras ou instauradoras em chave de imanência carregam preconceitos (as primeiras, de que a religião é uma ilusão, e as segundas, a da neutralidade científica) e que as hermenêuticas instauradoras em chave de transcendência, apesar de também possuírem seu pressuposto (o da existência de uma realidade transcendente), são justificáveis porque é assim que os sujeitos religiosos a compreendem, esses estudos demonstram considerar a experiência religiosa como direta ou imediata, visto que se apresentam como um "dado de experiência vivida" (GRECO, 2009, p.234). No entanto, como veremos adiante, se levarmos a hermenêutica filosófica às últimas consequências, podemos dizer que não há experiência (inclusive religiosa) imediata e que, mesmo para o sujeito religioso, a realidade experimentada como dada só assim o é porque ele também já carrega determinados pressupostos.

Com isso, a hermenêutica filosófica, nessa perspectiva, acaba sendo utilizada principalmente de maneira instrumental, sem ir a fundo na reflexão de seu caráter ontológico, que questiona a metafísica, proposta por Heidegger e Gadamer. No intuito, então, de tentar superar uma dicotomia ainda existente no campo da(s) Ciência(s) da(s) Religião(ões) e o risco de dogmatismos tanto em vertentes críticas e funcionalistas, quanto em vertentes essencialistas, nossa proposta é retomar o caminho indicado por Gadamer, colocando a questão da experiência religiosa a partir de sua reflexão sobre a experiência hermenêutica, em interlocução com outros estudiosos contemporâneos da religião. A ideia é incorporar a radicalidade do pensamento do autor e, a partir do que se observa como a universalidade do problema hermenêutico, não pensar apenas em uma hermenêutica da religião, mas na própria religião como hermenêutica. E mais ainda, na experiência religiosa como experiência hermenêutica, ou seja, não como uma simples experiência de contato com uma realidade religiosa e sua interpretação a posteriori, mas como lugar de compreensão e acontecimento da verdade. 


\section{Experiência religiosa enquanto experiência hermenêutica}

Vimos que, na modernidade, a reflexão filosófica a partir da hermenêutica contribuiu de maneira importante para os estudos sobre a religião, tanto numa tendência mais crítica quanto numa tendência fenomenológica. No entanto, em ambos os casos, ou seja, assumindo ou não a existência de uma realidade religiosa ou o fenômeno religioso como esfera cultural autônoma, podemos dizer que a hermenêutica é ainda considerada de maneira instrumental, principalmente como ferramenta para interpretação de símbolos, narrativas e práticas religiosas. Embora às vezes também os próprios símbolos e textos religiosos, por exemplo, possam ser olhados de um ponto de vista hermenêutico (ou seja, admite-se que tais "produções religiosas" sejam construções humanas, ou interpretações de algo "revelado"), permanece a ideia de que há uma experiência religiosa originária, imediata, experimentada pelo sujeito religioso de maneira direta e que somente depois ocorre uma "elaboração hermenêutica", que identifica, nomeia e compreende a realidade experimentada, para então organizar e divulgar essa experiência na forma de mitos, ritos, doutrinas etc. (por meio do que seria, então, a linguagem religiosa).

No entanto, considerando a hermenêutica filosófica de Gadamer, parece-nos insuficiente entender o assunto dessa forma. Voltando a definição de Grondin, de religião como culto crente que se traduz por símbolos que reconhecem um sentido para a existência, propomos olhar hermeneuticamente para essa experiência de sentido realizada pelo indivíduo (em vez de um olhar que, historicamente, como pudemos perceber, foi, em grande parte, fenomenológico), não no intuito, portanto, de apreender dela sua "essência", mas para compreendê-la melhor, à luz de como ela se apresenta, principalmente, na atualidade, quando a metafísica se coloca como um problema inclusive dentro do fenômeno religioso.

Assim, analisando a definição de religião apresentada e as reflexões realizadas em torno do conceito de experiência religiosa, poderíamos dizer que este tipo de experiência pode ser visto sob dois aspectos. Um mais associado às características devocionais e racionais da religião (a dimensão de culto e a dimensão de crença) e um outro correspondente à experiência "de sentido" observada nelas. No primeiro aspecto, a experiência religiosa seria aquela relacionada mais com a ideia de experiência empírica (uma experiência ritual, por exemplo) ou de experiência subjetiva (no sentido da fé como uma crença racional ou no sentido da experiência psicológica do sujeito). Já o 
segundo aspecto podemos remeter à experiência religiosa individual, mais "originária" (no ponto de vista fenomenológico) ou "autêntica" (no ponto de vista gadameriano). É sobre essa "experiência religiosa", portanto, que nos debruçamos neste artigo, trazendo algumas breves definições de experiências deste tipo para, a partir daí, propor uma nova leitura a partir de Gadamer.

Paul Tillich, importante teólogo protestante na primeira metade do século XX, por exemplo, define religião como "preocupação última" (cf. FILORAMO e PRANDI, 1999, p.267-268). Retomando esse conceito, Greco afirma que "a experiência religiosa é a oferta de um sentido último e definitivo da realidade, que envolve a totalidade da pessoa" (GRECO, 2009, p.201). Karl Rahner, um dos mais influentes teólogos católicos do século XX, a definiu como uma "experiência transcendental" que opera "em todos os seres humanos". Para ele, conforme nos apresenta Faustino Teixeira, "cada consciência subjetiva estaria assim animada por esse 'caráter ilimitado de abertura", na medida em que, "enquanto ser de transcendência, o ser humano está sempre, e antes de qualquer ato de liberdade, situado e orientado na atmosfera de um 'mistério santo e absolutamente real"' (TEIXEIRA, s.d., s.p.).

Henrique Claudio de Lima Vaz diferencia conceitualmente "experiência religiosa" daquela que ele chama "experiência de Deus", sendo a experiência religiosa uma "experiência do Sagrado" e a experiência de Deus uma "experiência do Sentido radical". Para ele, "o religioso ou o Sagrado resultam da função simbolizante do homem nesse terreno que se estende entre o fascínio e o temor do que é incompreensível ou misterioso" (LIMA VAZ, 2014, p.250). Já a experiência de Deus ou do divino seria a tradução de "um Sagrado primordial", que ocupa "o espaço total onde as dimensões da existência - e da experiência - se desdobram” (LIMA VAZ, 2014, p.252). Para o autor, isso quer dizer que a experiência religiosa não é, especificamente, uma experiência de Deus e a experiência de Deus não é, estruturalmente, uma experiência religiosa. No entanto, indica que "a verdadeira experiência de Deus", da forma como ele demonstra ser experimentada, pode estar ligada a uma experiência religiosa de caracterização mística (entendida por ele como uma experiência "trans-racional") (LIMA VAZ, 2014, p.248).

De fato, considerando estudos e relatos de místicos, parece ser essa dimensão do sentido, conforme identificada pelos autores citados, que é experimentada. Do ponto de vista cristão, uma experiência mística é "uma experiência do mistério do totalmente Outro, um conhecimento desse Outro por experimentação" (sendo o Outro, nesse caso, identificado como 
o próprio Deus) (BINGEMER, s.d., s.p.). Muitas vezes, essa experiência é descrita pelos próprios místicos como uma experiência direta e imediata com um "Absoluto" e que, embora haja a compreensão de uma totalidade que se desvela, há também o sentimento de que há muito a ser revelado (e que nunca será revelado em sua amplitude).

Diante disso, percebemos que, no fundo, ainda se compreende a experiência religiosa dentro dos limites da subjetividade do sujeito e admitese a existência ou presença de um outro que, embora entendido como mais amplo do que um Deus pessoal, ainda representa a ideia de uma realidade transcendente. Além disso, para esses estudiosos, bem como para os próprios místicos que experimentam essa verdade, a experiência religiosa parece ocorrer de maneira imediata, sem a mediação da cultura, da tradição e da linguagem. No entanto, vimos anteriormente que a linguagem é condição mesma de possibilidade da experiência. Como afirma Pieper:

Ambas ocorrem conjuntamente, de modo que a experiência do sagrado, mesmo quando se autodenomina inefável, é mediada pela linguagem. Não há experiência pura e imediata. A experiência religiosa, inclusive a mais mística, inscreve-se num horizonte de compreensão de modo que não se estende para além da linguagem, o que impactaria na sua ininteligibilidade. [...] A hermenêutica filosófica pode nos auxiliar na compreensão desta cumplicidade entre experiência e linguagem. Nesse sentido, é importante superar aquilo que Heidegger denomina de compreensão instrumental da linguagem, tida como mero meio de comunicação. (2011, p.372).

Assim, é interessante observar que mesmo que o místico afirme ter, de alguma forma, compreendido o "Mistério" sem amarras ou mediações, entendemos que as imagens, símbolos e referências prévias utilizadas, ainda que inconscientemente, para que a experiência ocorresse refletem essa mediação total da linguagem, como explicitada por Gadamer. O uso da imaginação pessoal para a contemplação inaciana, por exemplo, ou a imagem do castelo interior para Santa Teresa, e até mesmo o fato de nomearem o "absoluto" como Deus (ou até mesmo como Absoluto), não são apenas ferramentas para alcançar esse "absoluto" de maneira plena e total, ou sugestões elaboradas após as experiências como maneira de entendê-las e divulgá-las, mas pré-conceitos essenciais à compreensão e o que tornam possível a própria experiência naquele momento (e a própria identificação da existência de algo como um "absoluto”). Como afirma Gianni Vattimo, "a formação do 
conceito da coisa, a busca da palavra justa para uma certa experiência, não são esforços de registrar experiências já feitas, para determiná-las e comunicá-las, mas constituem a própria experiência» (VATTIMO, 2019, p.122, grifo do autor).

Nesses relatos, por mais que se tente, não há como separar as imagens, as narrativas, os nomes dados ao "Mistério" durante a experiência, com a própria experiência (ou seja, não há como suspender totalmente os preconceitos ou a influência da tradição, que fazem parte da estrutura de pré-compreensão daquele que experimenta). É aí que reside não só o reconhecimento de que toda descrição da experiência será apenas uma tentativa de descrever algo que parece inenarrável e indefinido, mas também uma certa angústia de que toda a experiência não tenha sido completamente vivida ou a verdade plenamente acessada (afinal, não se consegue de fato nomeá-la), embora haja também a inexplicável certeza de que ela foi alcançada e compreendida. Afinal, como afirma Gadamer, toda compreensão é já interpretação:

A possibilidade de compreender depende da possibilidade dessa interpretação mediadora. Conforme o caso, isso vale também onde a compreensão ocorre imediatamente e sem necessidade de assumir uma interpretação manifesta. Pois também nesses casos de compreensão deve ser possível a interpretação. Mas isso significa que a interpretação já está potencialmente contida na compreensão. A interpretação portanto não é um meio para produzir a compreensão, mas adentrou no conteúdo do que se compreende ali. [...] o que é a compreensão: uma apropriação do que foi dito, de maneira que se converta em propriedade de alguém. [...] Compreender e interpretar estão imbricados de modo indissolúvel. (GADAMER, 2015, p.515-516).

Lima Vaz parece se dar conta dessa questão ao explicar como seria possível ao homem experimentar o Sentido radical ou absoluto (segundo ele, a experiência de Deus). Para ele, é no espaço entre a presença e a consciência, circunscrito pelos limites do mundo, do outro e do eu (ou seja, o espaço da linguagem e seu conteúdo), que a consciência experimenta essa "presença onipresente". No entanto, essa presença, sendo um "fundo indeterminado dos sentidos possíveis", não se desvela radicalmente ou absolutamente. Apenas um "recorte", um sentido possível, se desvela. É por isso que, para ele, essa presença é, ao mesmo tempo, presente e transcendente. Assim, por um lado, como ela se dá no espaço da linguagem, podemos falar dela (não é indizível) e, de fato, ela só tem lugar na forma humana do discurso. Por outro lado, é também uma experiência da "impossibilidade de uma linguagem do absurdo 
radical do ser", na medida em que não pode se expressar ou é apreendida em sua totalidade. (LIMA VAZ, 2014, p.251-253, grifos do autor).

Se, por um lado, o teólogo admite o caráter ontológico da linguagem enquanto meio total da experiência, um entendimento mais radical do que pode significar essa ontologia parece limitado por um pensamento de que presença e consciência operam ainda em polos completamente distintos, e de que essa presença onipresente do Sentido radical está sendo considerada ainda na chave do transcendente enquanto realidade.

Considerar a experiência religiosa, mesmo em sua dimensão de sentido ou de encontro com a verdade, como uma experiência hermenêtica é, portanto, um caminho para superar essa chave e poder pensar a transcendência de outra forma. Nessa perspectiva, Aldo Gargani propõe:

Nossa visão permanecerá inevitavelmente superficial até que não tenhamos superado a metafísica dos objetos teológicos e até que não tenhamos superado aquele vértice que, coincidente com a experiência efetiva da atualidade da religião, reconhece no discurso religioso uma perspectiva hermenêutica por meio da qual devemos olhar para a vida. Veremos então cair, como distinções inertes, as dicotomias tradicionais entre vida terrena e vida celeste, inferno e paraíso, humanidade e divindade, para nos engajarmos no jogo mais alto e mais fecundo de suas afinidades e diferenças. [...] Uma vez desativada a sua carga metafísica, os objetos da tradição religiosa tornam-se figuras para uma perspectiva de interpretação da vida. [...] A transcendência apaga-se, deste modo, como repartição das raias ontológicas entre classes de entes, mas não se anula como ponto crítico da atividade de interpretação dentro do fluxo dos fenômenos da vida e da história. (2000, p.128-129).

\section{A universalidade da experiência de verdade}

Cremos que, após refletirmos sobre a experiência religiosa à luz do conceito gadameriano de experiência hermenêutica, podemos afirmar, junto com o autor, que tal experiência é própria do homem. Não por ser sua essência, no sentido de que todo homem experimenta tal coisa, ou por ser um a priori que todo homem encontra em si mesmo, ou ainda uma projeção do sujeito. É própria do homem porque é possível de ser realizada somente pelo homem e por qualquer homem, exatamente pelo caráter universal da linguagem, essa sim "essencialmente" humana. É uma capacidade, uma possibilidade, que se torna "real" na medida em que, sendo linguagem, o homem dialoga com a realidade. Tal constatação nos traz à afirmação da universalidade da experiência da verdade que se dá, segundo Gadamer, pela 
ontologia da linguagem, vista como mediação total, na qual é possível ao homem se expressar e conhecer a realidade. Não se trata, portanto, de uma ontologia que pensa o transcendente enquanto realidade, mas a possibilidade humana de transcender a realidade por meio da linguagem:

Este conceito de espírito, que transcende a subjetividade do eu, encontra o seu verdadeiro correspondente no fenômeno da linguagem, o qual hoje veio a encontrar-se sempre mais ao centro da filosofia contemporânea; e isso porque, em confronto com aquele conceito de espírito que Hegel retomou da tradição cristã, o fenômeno da linguagem possui a vantagem, adequada à nossa finitude, de ser infinito como o espírito, e contudo finito como cada acontecer. (GADAMER apud VAT'TIMO, 2019, p.109).

Assim, afirma Vattimo, "esta mediação total não pode ser pensada nem como um apropriar-se da coisa pela parte do intérprete (a autotransparência completa do espírito absoluto hegeliano), nem como uma subordinação teleológica da consciência subjetiva a uma ordem estavelmente dada do ser (como na metafísica tradicional)" (VATTIMO, p 2019, p.122). A linguagem é então o meio em que a experiência hermenêutica acontece, como elemento regente, não como instrumento. Ou seja, é a partir dela que o homem pode dar nome às coisas, definí-las, compreendê-las. Para isso, ele também se utiliza de instrumentos de linguagem, mas a linguagem em si é muito mais que isso. Os instrumentos de linguagem são vários, talvez tanto quanto as próprias coisas, e dependem de variadas condições (sociais, históricas, ambientais, políticas etc.) para serem como são. Esses instrumentos também transformam essas variadas condições, dando margem para que outros instrumentos surjam. É por isso que podemos falar em linguagem religiosa, linguagem artística, linguagem política, linguagem científica... Elas são modos de a linguagem humana (ou seja, a capacidade de nomear, definir, entender) atuar, ou ser "aplicada". É essa linguagem como capacidade humana que possui status ontológico para Gadamer. Para ele, "não há um dar-se das coisas para além da linguagem, em que a palavra se adicione como meio de conservação ou comunicação de uma experiência em si pré-linguística" (VAT'TIMO, 2019, p.122), a palavra é, desde sempre, parte constitutiva da experiência.

Para Gadamer, a atuação da linguagem, antes de ser um processo intelectivo, subjetivo, colocado em prática antes ou após algum tipo de reflexão racional, é um processo de experiência dialógica do homem no e com o mundo. Ou seja, é o modo como o homem pode "ser" no mundo 
e se relacionar com a realidade (que também só passa a "ser" por meio da linguagem, ao que ele chama de "linguagem das coisas"). É isso o que ele parece dizer quando diz que "o ser que pode ser compreendido é linguagem" (GADAMER, 2015, p.612). Essa frase não pode ser considerada relativista, no sentido de que o ser aqui não é necessariamente algo meramente subjetivo, nem meramente sensorial (para aqueles que associam experiência a sensação), uma vez que sensações também são vivenciadas pelos animais, por exemplo (e é por isso também que ele insiste que a linguagem não é mera ferramenta de comunicação, pois linguagem desse tipo também poderíamos dizer que têm os animais). É por isso que, a partir dessa frase também não podemos chegar ao ponto de declararmos que só há, então, a linguagem, no sentido instrumental, do discurso (como o fazem alguns nominalistas). Afirmar que o que pode ser compreendido é linguagem quer dizer que a compreensão somente se dá nessa dimensão. Por conseguinte, o ser nunca poderá ser entendido completamente. Isso porque a linguagem, em seu status ontológico, é, essencialmente, abertura. Se somente houvesse a linguagem, nesse sentido nominalista, poderíamos chegar a conclusão de que o ser poderia vir um dia a ser entendido completamente, na medida em que um consenso poderia o definir de modo absoluto. A partir do que Gadamer apresenta, portanto, poderíamos conceber esse ser enquanto linguagem como uma transcendência, mas no sentido de algo como um aberto situado ${ }^{2}$ :

Veja, trata-se do fato de que a transcendência é algo muito mais profundo. A metafísica que acreditava possuir a verdade que podia ser suficiente para tudo não é o que entendo como transcendência. A este saber não pode chegar nenhum de nós. Devemos admitir, no fundo, que nada sabemos. E então pode acontecer que cheguemos a crer, e precisamente porque, a cada vez que fazemos uma tentativa, que tratamos de nos perguntar o que é o milagre da vida, e também da morte, nos encontramos frente a um mistério que não conseguimos conhecer de forma alguma, que simplesmente é assim. O que é, então, a filosofia? Um saber totalmente circunscrito e determinado por limites. É por isso que temos a hermenêutica, essa tentativa de ir, de algum modo, mais além. Também em Heidegger acontece o mesmo, nunca sabemos o que é o ser, parece que se trata sempre de um topos, um lugar inacessível; assim

2 Utilizamos o termo situado tendo como base a seguinte colocação de Joel Weinsheimer: "'Situado' é como Gadamer descreve nossa relação com o ser (supraindividual): ele não localiza o que está além da consciência em um lugar metafísico, acima e fora do mundo. Muito pelo contrário, é precisamente o ser no qual estamos 'situados' que, embora próximo, também está mais além de nós” (WEINSHEIMER, 1999, p.ix-x, tradução nossa). 
ocorre em Ser e Tempo. Aqui do ser eu não sei nada, talvez eu saiba algo dele como um evento (Ereignis), mas talvez nem mesmo como um evento, porque esse evento é, no fundo, indescritível, indeterminável... (GADAMER, 2010, p.82, tradução nossa).

Ora, se admitimos que essa experiência hermenêutica autêntica da qual fala Gadamer corresponde àquela dimensão de verdade da experiência religiosa, devido a esse caráter universal da linguagem (como mediação total) e dela depender o acesso à verdade enquanto acontecimento, poderíamos afirmar então que não é somente na religião que essa experiência é realizada. Ou seja, não é somente por meio da experiência religiosa que se alcança a verdade, ou, em outras palavras, tem-se a experiência de ter compreendido o "sentido do ser" (ou algum sentido do ser). De fato, vimos com o autor que essa experiência ocorre também na arte e, em última instância, sempre que o homem realiza uma experiência hermenêutica autêntica com o mundo.

Um exemplo interessante do que estamos expondo pode ser observado na história abaixo, contada pelo teólogo, filósofo e psicanalista Antoine Vergote:

Uma estudante da Indonésia que passava algumas semanas na Bélgica foi a Bruges ver os célebres quadros de Memling. Ela ficou literalmente em êxtase diante das telas: o azul dos céus de Memling a cativou por uma profundidade infinita que tinha para ela o sentido de um mistério divino. Mais tarde, conhecendo melhor a religião cristã, a estudante se converteu. Então, depois do acontecido, ela pôde dizer a si mesma que o que percebera no mistério sagrado de um mundo de profundidade infinita evocado por Memling era o Deus santo de Jesus Cristo. Essa experiência concorda com aquilo que a reflexão crítica sobre a filosofia nos leva a pensar, bem como com aquilo que ilustra a história da filosofia. A jovem indonésia vira uma transcendência horizontal imanente ao mundo e que permanecia para ela como um horizonte aberto. Nessa abertura, veio situar-se o nome de Deus, e a jovem compreendeu que devia dar o passo da fé na direção desse Deus. (2002, p.126).

Vergote usa essa história para esclarecer sobre aquilo que chama de "transcendência horizontal imanente", uma transcendência que a razão filosófica busca como verdade infinita que permanece fora do alcance da apreensão racional e que, depois, parece apontar para um "horizonte de realidade mais ou menos transcendente", que, no caso dos convertidos é identificado como Deus mas, no caso de Aristóteles, que ele cita como 
exemplo, é identificado como a "verdade absoluta", uma "realidade que exerce sua influência sobre tudo o que se move" (VERGOTE, 2002, p.126-127).

Trazendo o exemplo para o que viemos refletindo sobre a experiência hermenêutica, aqui fica nítida a distinção entre aquela dimensão de sentido da experiência (a compreensão da verdade - nas palavras de Vergote, o "sentido de um mistério divino" - que a estudante experimentou ao contemplar o quadro) e a dimensão propriamente religiosa da experiência (aquela que ela denominou a partir de elementos religiosos). No caso de Aristóteles, pelo exposto pelo autor, frente a uma experiência de sentido realizada, o "nome" dado, ou seja, a caracterização dessa experiência, seria ainda numa perspectiva filosófica. Isso quer dizer que, como já sugerimos, tal experiência de verdade, aquela indicada por Gadamer como experiência hermenêutica autêntica, é universal e pode ser realizada em qualquer âmbito (até porque, como vimos anteriormente, de fato, esses âmbitos - ou esferas culturais - também não passam de classificações e não de realidades em si).

Alguns estudiosos também sugerem essa ideia, como o próprio Lima Vaz, como já vimos, e também Karl Rahner, para quem "esta experiência transcendental do sujeito vem marcada por universalidade, podendo ocorrer de forma atemática e mesmo 'arreligiosa', independente de uma experiência religiosa explícita. É uma experiência original, ontologicamente fundada” que "ocorre quando o sujeito se vê defrontado, no âmbito de suas atividades cotidianas, com o 'abismo de sua existência"” (TEIXEIRA, s.d., s.p.). É por isso que Faustino Teixeira sugere que seja feita uma distinção entre religião e espiritualidade.

Citando Dalai Lama, afirma que a espiritualidade está relacionada com "qualidades do espírito humano" (tais como o amor, a compaixão, a paciência, a hospitalidade, a atenção, delicadeza e doação) que "independem de uma vinculação religiosa". Nessa perspectiva, o autor cita ainda Pierre Hadot, que fala em "exercício espiritual" como uma "prática voluntária e pessoal de desapego e transformação de si mesmo, de descentramento do ego em favor de uma aliança superior do sujeito com a totalidade das coisas" (TEIXEIRA, s.d. s.p.). Parece ter sido isso também o que tentou fazer Lima Vaz ao diferenciar a experiência religiosa da experiência de Deus (ou do Sentido radical). No entanto, o nome que ele deu a essa dimensão da experiência que estamos chamando aqui de experiência de verdade é problemático. Afinal de contas "Deus" é uma palavra notadamente religiosa o que pode levar a novas confusões. 
Teixeira também comenta que "uma série de autores não religiosos têm hoje sublinhado a importância da vida espiritual como traço elevado do ser humano, e capaz de ser experimentado mesmo fora de uma inserção religiosa". Como exemplo, cita André Comte-Sponville que, em seu livro $O$ espirito do ateísmo, indica que "a espiritualidade tem a ver com a abertura do espírito e o defrontar-se com a vida em profundidade" e é algo que "se dá, de forma simples e até mesmo banal, no domínio da experiência cotidiana, diante da força da "imanensidade"" (TEIXEIRA, s.d., s.p.). De fato, ComteSponville é hoje conhecido como o "místico ateu”.

Analisando tudo o que vimos e observando que há uma dimensão daquilo que consideramos "experiência religiosa" que poderia ser associada à experiência de verdade, e que essa dimensão não é específica da experiência religiosa, entendemos ser um problema utilizar o termo religioso como algo considerado universal, principalmente em nosso campo de estudos. É certo que, diante de tantas transformações nessa esfera da cultura e, inclusive, do esfumaçamento das fronteiras entre as diversas esferas culturais, além da constatação, exatamente, do caráter universal deste tipo de experiência, é compreensível que o conceito de religião seja usado em um sentido mais amplo. O problema está em associá-lo necessariamente a esta dimensão da experiência que pode ser encontrada por toda a parte.

Isso porque tais concepções carregam o risco da possibilidade de se pensar em um fundamento religioso para qualquer âmbito da cultura, e, no limite, de se justificar a existência de uma realidade religiosa a priori. Em um artigo em que foi publicado um autorrelato de uma experiência "mística" de Comte-Sponville, por exemplo, o articulista chegou a se questionar, contrariando as próprias reflexões do autor, se ele seria mesmo ateu, perguntando-se se o que ele afirma ter sentido em um momento de contemplação da natureza e do universo junto a amigos não teria sido, afinal, "um contato imediato com o Todo, com a Presença, com a Realidade mais genuína e originária, sem fragmentação temporal ou conceitual”, aquela que "as religiões denominam Deus, Espírito criador, Transcendente e Imanente" (HAYA, 2011, s.p.).

Também não é incomum observarmos algumas confusões em nosso campo de estudos ao tratarmos de temas como espiritualidade e saúde, religião e política ou religião e educação, por exemplo, quando, muitas vezes, no intuito de legitimar esse aspecto "espiritual" ou essa dimensão de sentido ou de experiência da verdade do fenômeno religioso, acaba-se naturalizando 
alguns pressupostos religiosos ou considerando como verdades absolutas certas concepções metafísicas específicas (ainda que sob um viés mais pluralista). Por outro lado, no intuito de criticar ou estudar apenas alguns elementos religiosos (tais como práticas, dogmas e instituições), acaba-se negligenciando essa dimensão de verdade do fenômeno religioso, negando, muitas vezes, sua importância enquanto esfera cultural autônoma e a própria experiência dos sujeitos religiosos.

Por isso, a partir da problematização que apresentamos do conceito de religião, demonstrando que, do modo como o usamos hoje, trata-se de uma classificação principalmente moderna, entendemos que, com Gadamer, uma ontologia do religioso não é possível. A religião passa a ser apenas uma das formas (por certo, talvez uma das mais privilegiadas, devido à autonomização das esferas da cultura na modernidade e às características de sua linguagem) daquela experiência de verdade, proporcionada, aí sim, por uma ontologia da linguagem. Nesse sentido, podemos optar por falar de experiência religiosa quando aquela a que nos referimos possui, de fato, elementos (como práticas e linguagens) reconhecidos como religiosos, a partir, obviamente, de conceitos formulados como tal ao longo de nossa tradição ou, simplesmente, assumidos como nosso horizonte de observação.

Sobre a dimensão da experiência religiosa analisada neste artigo enquanto "experiência hermenêutica autêntica", privilegiamos chamá-la de "experiência de verdade", pois nossa proposta era evidenciar exatamente essa dimensão da experiência humana em que a verdade acontece e se dá uma compreensão de sentido. No entanto, entendemos que também essas expressões, fora do âmbito desta pesquisa, possam não ser claras ou úteis para serem aplicadas. Tendo em vista, então, o que foi apresentado, e dado o uso que se fez aqui e que se faz na atualidade do termo "espiritualidade" (ou da expressão "experiência espiritual"), talvez esta seja, por ora, uma definição apropriada. No entanto, é importante lembrar que, da mesma forma como foi feito com o conceito de religião e de experiência religiosa aqui, sempre que o termo "espiritualidade" for utilizado (ao menos no campo acadêmico), é razoável que uma problematização desse conceito seja desenvolvida.

Por fim, não pretendemos, portanto, ter apresentado algo como uma definição de experiência religiosa, mas esperamos que tenha ficado evidente a necessidade desse conceito ser sempre problematizado, ao ser usado em qualquer perspectiva - científica ou não - que busque compreendêlo ou dialogar com ele. No entanto, pudemos perceber também que essa 
problematização poderá ser de grande valor para o campo caso seja realizada sob o prisma da hermenêutica filosófica, uma vez que, a partir daí, podemos vislumbrar um olhar sobre a experiência religiosa e o fenômeno religioso que tenta superar (ou se colocar "entre") a dicotomia ainda existente entre aqueles que consideram o fenômeno apenas como uma construção humana, ignorando a experiência vivida pelo homem religioso, e aqueles que consideram tal experiência e buscam definí-la criando categorias universais, o que muitas vezes dá margem para que se possa dizer que há realidades mais "verdadeiras" que outras.

Nessa perspectiva, acreditamos que podemos concluir que qualquer religião que, em alguma medida, possibilite uma experiência religiosa em sua dimensão hermenêutica autêntica pode ser considerada como lugar em que a verdade se dá a conhecer. Tal conclusão é importante não só para a defesa da religiosidade enquanto modo legítimo de compreensão da realidade, frente a outras formas do conhecimento humano, como também para que as religiões, entre em si, possam dialogar. No entanto, ao concluir também que o acontecimento da verdade não é privilégio do fenômeno religioso, abre-se espaço para que possamos pensar no tema da espiritualidade de uma maneira mais ampla, que abarque a pluralidade existente no mundo contemporâneo (e seus movimentos espiritualistas e de "novas religiosidades") e nos ajude a levantar mais elementos para refletir e discutir sobre o papel da religião em outros âmbitos da vida humana, como a cultura, a educação, a saúde, o meio-ambiente, a economia e a política.

\section{Referências}

ALES BELLO, A. Cultura e religiões: uma leitura fenomenológica. Bauru, SP: EDUSC, 1998.

ANDRADE JÚNIOR, G.S. A liberdade no pensamento de Heidegger e Gadamer. In: Revista Eletrônica do Curso de Direito - PUC Minas Serro, n.1, 2010.

AZEVEDO, C.A. A procura do conceito de religio: entre o relegere e o religare. In: Religare, João Pessoa, v. 7, n. 1, p. 90-96, mar. 2010.

BINGEMER, M.C. Mística e espiritualidade. In: Enciclopédia Digital Theologica Latinoamericana. Belo Horizonte, MG: FAJE, s.d., n.p. Disponível em: <http:// theologicalatinoamericana.com/?cat=50> Acesso em: 14 de abril de 2019. 
CROATTO, J.S. As linguagens da experiência religiosa: uma introdução à fenomenologia da religião. São Paulo: Paulinas, 2001.

DERRIDA, J. Fé e saber: As duas fontes da "religião" nos limites da simples razão. In: VATTIMO, G. e DERRIDA, J. (orgs.) A Religião: o seminário de Capri. São Paulo, Estação Liberdade, 2000.

FILORAMO, G.; PRANDI, C. As ciências das religiões. São Paulo: Paulus, 1999.

GADAMER, H.G. Verdade e Método I: traços fundamentais de uma hermenêutica filosófica. 15.ed. Petrópolis, RJ: Vozes; Bragança Paulista, SP: Editora Universitária São Francisco, 2015.

GADAMER, H.G. Verdade e Método II: complementos e índice. 6.ed. Petrópolis, RJ: Vozes; Bragança Paulista, SP: Editora Universitária São Francisco, 2011.

GADAMER, H.G. El último dios: La lección del siglo XX. Hans-Georg Gadamer en diálogo filosófico con Riccardo Dottori. Rubí (Barcelona): Anthropos Editorial; México: Universidad Autónoma Metropolitana, Cuajimalpa, 2010.

GARGANI, A. A experiência religiosa como evento e interpretação. In: VATTIMO, G. e DERRIDA, J. (orgs.) A Religião: o seminário de Capri. São Paulo, Estação Liberdade, 2000.

GRECO, C. A Experiência religiosa: Essência, valor, verdade: um roteiro de filosofia da religião. São Paulo, SP: Edições Loyola, 2009.

GRONDIN, J. Que saber sobre Filosofia da Religião. Aparecida, SP: Ideias \& Letras, 2012.

HAYA, G. Comte-Sponville, um místico ateu no século XXI. In: Revista IHU Online, reportagem publicada em 13 de maio de 2011. Disponível em: <http://www.ihu.unisinos.br/ noticias/43246-comte-sponville-um-mistico-ateu-no-seculo-xxi> Acesso em: 13 de novembro de 2019.

HEIDEGGER, M. Fenomenologia da vida religiosa. Petrópolis, RJ: Vozes; Bragança Paulista, SP: Editora Universitária São Francisco, 2010.

HIGUET, E.A. Hermenêutica da religião. In: Passos, J.D., Usarski, F. (orgs.). Compêndio de ciência da religião. São Paulo: Paulinas; Paulus, 2013.

LIMA VAZ, H.C. Escritos de Filosofia I: Problemas de fronteira. 4.ed. São Paulo: Edições Loyola, 2014.

OTTO, R. O sagrado: os aspectos irracionais na noção do divino e sua relação com o racional. São Leopoldo: Sinodal/EST; Petrópolis: Vozes, 2007.

PEREIRA, V.M. Sobre a tese "ser que pode ser compreendido é linguagem": hermenêutica como teoria filosófica. In: Cadernos de Filosofia Alemã, v.20, n.2, 2015. 
PIEPER, F. Experiência religiosa e linguagem: considerações hermenêuticas. In: Síntese, Belo Horizonte, v.38, n.122, 2011.

PIEPER, F. Problematizando o conceito de religião: considerações hermenêuticas. In: SILVEIRA, E.S.; COSTA, W.R.S. (Orgs.). A Polissemia do Sagrado: desafios da pesquisa sobre religião no Brasil. São Paulo: Fonte Editorial, 2015.

PIEPER, F. Religião: limites e horizontes de um conceito. In: Estudos de Religião, v.33, n.1, 2019.

SEIBT, C.L. Considerações sobre a fenomenologia hermenêutica de Heidegger. In: Rev. NUFEN, Belém, v.10, n.1, 2018.

TEIXEIRA, F. Experiência religiosa: abordagem das ciências da religião. In: Enciclopédia Digital Theologica Latinoamericana. Belo Horizonte, MG: FAJE, s.d., n.p. Disponível em: <http://theologicalatinoamericana.com/?p=203> Acesso em: 14 de abril de 2019.

VATTIMO, G. A ontologia hermenêutica na filosofia contemporânea: Introdução a Verdade e Método, de Hans-Georg Gadamer. In: Pensando - Revista de Filosofia, vol.10, n.19, 2019.

VERGOTE, A. Modernidade e cristianismo: interrogações e críticas recíprocas. São Paulo: Edições Loyola, 2002.

WEINSHEIMER, J. Translator's preface. In: GADAMER, H.G. Hermeneutics, Religion, and Ethics. New Haven and London: Yale University Press, 1999.

Submetido em: 10-01-2020

Aceito em: 14-8-2020 